\title{
The Middle East Policy-Future Engagements of the U.S in Iran
}

\author{
Abdulrahman Al-Fawwaz ${ }^{1}$, Abdallah S. Abualkanam ${ }^{2}$ \& Walid K. Abudalbouh ${ }^{3}$ \\ ${ }^{1}$ Department of Humanities, Al-Balqa Applied University, Jordan \\ ${ }^{2}$ Faculty of Arts and Sciences, Ahliyya Amman University, Jordan \\ ${ }^{3}$ International Relations Department, University of Jordan, Jordan \\ Correspondence: Abdulrahman Al-Fawwaz, Department of Humanities, Al-Balqa Applied University, P.O.Box: \\ 15008, Amman 11134, Jordan. Tel: 962-7-7740-4832; 962-6479-0333. E-mail: dr_fawwaz77@bau.edu.jo; \\ fawwaz77@yahoo.com
}

Received: July 20, 2019 Accepted: August 26, 2019 Online Published: August 30, 2019

doi:10.5539/jpl.v12n3p148 URL: https://doi.org/10.5539/jpl.v12n3p148

\begin{abstract}
The U.S is one of the foreign nations that have been deeply involved in the affairs of the Middle East region, particularly in Iran. The threat posed by terrorism to international peace and stability was one of the reasons why the U.S thought it wise to be involved in the affairs of the Middle East. Besides the insecurity concerns, laid the interests of the U.S in the region that is known to have vast reservoirs of oil and the leading producers of the source of energy in the world. According to the U.S, it would have been foolhardy to let the region slip into an era of political unrest as the rest of the world watched, yet the region is a source of livelihood and economies of different nations the world over because of their vast oil deposits. Consequently, the U.S drafted several measures and policies that, according to them, were aimed at restoring peace and political stability in the region. These included coalition building, supporting peace ventures, and provision of humanitarian aid. In their policies, they believed that a stable Middle East region would ensure a more stable world than was witnessed before their involvement. Despite their involvement in trying to find lasting peace in the region, the U.S has also encountered several challenges along their way that made their peace efforts slip every moment they thought they were close to finding lasting peace in the region.
\end{abstract}

Keywords: Middle East, Iran, United States of America, coalition building, United Nations, peace, stability

\section{Introduction}

In the recent past, the Middle East region has experienced immense changes in its economic, political, and social environments that have had their consequences on the livelihoods of the inhabitants. These changes extended to the neighboring North Africa where popular uprisings were witnessed as the clamor for responsive and accountable governments took center stage. The consequences were that authorities that were deemed to be dictatorial were overthrown, and new administrations believed to be democratically installed in those countries. These changes brought with them a raft of economic and political changes that spread across the Middle East region and Iran in particular. The region that was hitherto unstable because of different reasons thought that the changes would have brought better living standards to their citizens. However, the instability witnessed in the region in the preceding years aside; the region was also concerned over several issues such as insecurity and economic slump downs(Chomsky, Achcar, \& Shalom, 2015). These complaints could have been borne out of their governments, or as a result of international involvements in the region. The challenges thus put their involvement in the region in a precarious situation going forward. Therefore, this paper would examine some of the triumphs, challenges, and the future of the U.S in the Middle East region and with emphasis on Iran. Also, the study will focus on the influence that the other foreign nations have had about their relationship with the U.S in as far as the Middle East peace processes were concerned.

\subsection{Problem Statement}

Within the U.S, there have been developments that had caused worries and panic to the country in the Middle East, and in particular in Iran (Tajbakhsh, 2019). According to Duncombe (2019), for a long time, the U.S held the belief that Iran was on a course of developing dangerous and ballistic missile technology and at the same time promoting conflicts in the world by supporting the rebellion in the Middle East (Lowenthal, 2018). Cordesman (2018) also argues that Washington believed that Tehran is the biggest financier of proxy groups in the region and the leading 
state in the world in sponsorship of terrorist activities (Byman, 2014). According to the U.S, Iran spends billions of dollars to this effect in addition to developing and testing of ballistic missiles contrary to the resolutions of the UN. The perceived criminal activities of Iran in Syria and Yemen, as well as its perceived support for the Hezbollah in Lebanon, have continued to stoke conflicts in the region and undermine any positive efforts in the realization of peace in the region (Tielemans, 2019). Consequently, the U.S has been looking at options of cutting off any revenue to the Iranian administration so that they are deprived of the financial support they give to terrorism and terrorist activities in the region. To thwart these efforts, the U.S realized that it was a war they could not win on their own. Therefore, the idea of forming allies to add pressure to Iran, and to punish them economically was floated. In this regard, the U.S with the backing of the UN and allied nations imposed sanctions on Iranian oil exports cutting off revenue to the Iranian government since 2018. Also, the pressure campaign to cut off revenue to Iran saw some multinationals reduce their purchase of crude oil from Iran to zero. These actions, according to the U.S have been critical in curtailing the influence of Iran in the region by denying them of the critical revenue they needed to advance their agenda of sponsoring terrorists and terrorism in the region and elsewhere around the world.

\subsubsection{Religion}

Religion has been one of the underlying factors in the involvement of the U.S in Iran as it sought to protect its interests in the region. With the world status of the U.S, they wanted to shield their allies and business interests in the region from the violence and instability. Key among them is the nation of Israel. Israel since its independence in 1948 has been heavily reliant on the protection of the U.S against her adversaries in the region who felt that they were positioned in the wrong place and should not exist as a nation in the region. According to sources in the Middle East, religious affiliations were one of the reasons for their enmity with Israel (Kovjanić, 2014). In a region that is widely Islamic, the nation of Israel is majorly Jewish, a trait that its neighbors use to delineate them from the region. They believe that Israel should be wiped out of the region and the map of the world, an opinion that has often brought frictions and acts of political violence in the region between the Jewish Israelites and the Islamic nations in the region. In defense of Israel is its ally, the U.S that has stood with them against all the atrocities and acts of violence that have been meted against the nation by its neighbors. The issue of religion in the region has so deeply divided the nations that reconciliation efforts and plans for peace have always flopped at every instance that they have been organized.

\subsubsection{Economic Interests}

Another underlying issue at the center of U.S engagement in Iran is the protection of the nation's economic interests in the region, particularly the vast oil deposits in the region (Constantin-Bercean, 2018). It would also be noteworthy to note that oil and petroleum products drive most economies of the world. Consequently, any nation that has access to the oil wells in the Middle East can be self-reliant and stabilize their economies. On the contrary, these nations could also deny other countries access to petroleum products, thereby disabling their economic growth in different spheres. To spur economic growth in their motherland, the U.S needs access to oil wells in the Middle East and an unlimited supply of the vital commodity for its industrial development (Claes, 2018). Consequently, according to Washington, it would be important to form coalitions with other nations in the region to ensure that the U.S would not get deprived of the important commodity and to ensure that they continue to prosper industrially.

\subsubsection{International Security and Terrorism}

Terrorism and terrorist's activities pose the single biggest threat to international peace and stability. Terrorists' activities have been witnessed the world over and have caused untold suffering and deaths to millions of people of different nationalities, races, and religions. The terror cells have mostly been associated with unstable and insecure nations that cannot deal with internal rebellion and rebel groups within their borders. On the other hand, terrorist took advantage of the instability in the region to construct their terror cells in different countries in the region. Their threats were not only felt in the region but the world at large. As a result of the instability in the region, dismantling the terror cells and stopping the terrorist activities became a major problem for these nations. The terrorists as such found themselves taking sides in the conflicts by supporting sides in the conflicts. For example, Hezbollah in their efforts to defeat the Israeli and the U.S presence in the region was supported by Iran. Restoration of peace and stability in the region and protection of U.S nationals at home and overseas became a priority for the U.S in the region.

\subsection{Aims of the Study}

This study aims to assess the reasons for the involvement of the U.S in the political and economic affairs of Iran in particular and the Middle East in general. Also, the study will examine the consequences of U.S engagement in the 
region and Iran. Lastly, the study would consider the forecasts of the U.S engagements in Iran and the Middle East in the future.

\subsection{Objectives of the Study}

- To inform the readers about the issues in Iran that required the intervention of the international community and the U.S in particular

- To establish the relevance of the U.S participation in Iran and the Middle East region

- To bring to light the progress made by the U.S in its to restore normalcy and peace in Iran and the restoration of democratic rule in the region

- To pinpoint the engagements of the other international players in the problems in Iran and the Middle East

- To suggest a way forward for the U.S commitment in Iran and the Middle East in the future

\subsection{Questions and Hypotheses}

On completion of the study, the following pertinent questions raised in its course would need to be answered;

- What are the causes of conflict in Iran and the Middle East in general?

- Which parties are involved in the conflict?

- What is the international community doing about the conflicts?

- What role does the U.S play in the Iranian conflict?

- What are the possible solutions to the conflict?

\subsection{Possible Hypotheses}

The study would highlight the sectarian divisions in Iran as the leading cause of the conflicts in the nation and the region at large. Furthermore, the study would touch on the parties involved in the Iranian conflict as well as their possible sponsors. Additionally, the study would highlight the role of international organizations such as the UN and the role of the U.S in the conflict. Lastly, the study would suggest the possible solutions to the conflict in Iran, how the engagement of the U.S in Iran and the region, in general, would help in bringing solutions to the problems in the region.

\subsection{Methodology}

The study will focus on interviews by senior officials and diplomats from the U.S administration and documented efforts by the UN in attempts to solve the conflict in the region. The study will also rely on published journals about the conflicts in the region and other documentaries that in the past highlighted the issues in the region. These diplomats' views would be selected based on their appearances in the peace processes and participation in the formulation of the U.S foreign policy in the Middle East.

\subsection{Significance of the Study}

This study is expected to enlarge the knowledge to the world about the problems that the people of Iran and the Middle East face and the root causes of those conflicts. Additionally, the study would expand the knowledge of why the intervention of the U.S was necessary, and why their peace and stability restoration and humanitarian assistance measures need to be supported. Further, the study would also highlight the need for the world to rally behind the UN in its efforts to restore peace in the region and to find political solutions to the conflicts in the region. Lastly, the study would also make some of the possible proposals that could influence future engagements of the U.S and the international community in Iran and the Middle East.

\section{Literature Review}

According to Marantz, Steinberg, Sigler, and Sandler (2019) the U.S, participation in the Middle East peace processes has been a top priority for successive regimes. The U.S policymakers would want a secure, strong, and economically vibrant, Middle East as one of their major interests in the region. Moreover, by the U.S foreign policy agenda, successive governments of the U.S have been under the obligation to protect their homeland and that of their people at home and abroad. In realization of that mandate, they would have to form allies and work with those allies to counter any threats to their security anywhere in the world, including Iran. The activities involved in the security operations involved countering any terrorist activities with their intelligence, including nations that they believed supported and harbored terrorist groups. The U.S believed that stability in Iran would ensure that essential commodities and international businesses continued without any hindrance, thereby ensuring economic growth in most countries and the global economy as a whole. Stability in Iran, according to the U.S, 
would also mean an end to the proliferation of small arms and weapons of mass destruction that threatened international peace and cordial relations between nations. Stability in Iran, U.S diplomats observed would also make the region open up to international investments, thereby boosting the economies of the nations in the region. The restoration of peace and stability in Iran would go along way in ensuring that the U.S allies in the Middle East such as Israel will have peace, at least according to U.S sources.

Hinnebusch (2018) observed that in dealing with the problems in the Middle East, the U.S opted for coalition building; that is creating coalitions with friendly nations and those with interests of restoring peace and stability in the region to defeat the organizers of the frequent unrests. For example, in the battle to dismantle the ISIS or the Middle East Strategic Alliance, the U.S knew that they could not battle the groups alone. That is why they identified allies with whom they could collaborate and also promoted the economic prosperity of such nations as well as aiding them to be self-reliant (Paffenholz and Zartman, 2019). In as far as the security of the Middle East region is concerned, according to the U.S, Iran posed the single biggest threat to its stability (Cordesman, 2018). Sources in Washington believed that Iran did not only stoke conflicts with Iraq, Syria, and Yemen but that they also financed the activities of terrorist groupings like the Hezbollah. In the view of Bilgin (2019), the U.S thus opted for partnerships to negatively influence Tehran's activities that were spread throughout the world aggressively. Consequently, the U.S resolved to back the UN-led peace efforts in the Middle East, which they opined was the biggest single organization capable of restoring order in the region. However, the U.S restated its efforts in offering humanitarian aid to victims of any unrest or violence in the region. The commitment to offer aid and assistance to the vulnerable population also went in hand with their initiatives in protecting human rights and giving everyone freedom of religious association.

\section{Analysis and Discussion}

\subsection{The U.S and Coalition Building in the Middle East}

According to Washington, there are real threats to U.S nationals and economic interests that emerged from the instability in Iran. These threats convinced Washington on the desire to face the issues in Iran in collaboration with other friendly nations that also viewed the instability in the country as a threat to world peace. The collaboration approach with other countries was to ensure that the allies of the U.S in the region had enough capacity to offer solutions to the evils that were bedeviling the region (Krieg, 2016). The United States, according to sources, would not want to tell the people of Iran how to live, but rather to participate in their daily activities as partners based on shared values and principles. This, they observe would mean a better future for every citizen of every country wherever they would be. The defeat of the ISIS in Syria and Iraq was a testimony that when countries came together to defeat a common enemy, they could easily win the war, hence, the insistence of the U.S to confront the issues in Iran with allied forces. According to sources, the territory that was once occupied by the ISIS had been liberated, and currently, the issue of its stability remains the main focus. Although the ISIS was defeated, the group could be re-strategizing and could regroup and destabilize the efforts gained in the fight so far. That is why the U.S and its allies have been involved in activities aimed at stabilizing, counter-attacking the ISIS intelligence, and involvement in law enforcement activities that could prevent the ISIS from attacking their homeland.

\subsection{Improved Regional Ties}

The realization that the U.S may never go it alone in its mission to achieve peace and stability in Iran has brought a new wave of improved relationships with the nations of the region. For example, soon after the defeat, if the ISIS, the U.S undertook to work closely with the Iraqi administration to help them recover from the effects of the ISIS control in the region. Also, they worked closely with Iraq to ensure that they achieved their full prospects in terms of independence, success, and strength as a country. The fruits of the joint coalition saw the Iraqi government invite the allied forces to help them in the stability efforts as well as wiping out any remnants of the ISIS in the region. It would be important to add that the efforts and the results of the coalition built to wipe out the rebel and terror groups in the region improved the ties between the U.S and the countries in the region. Nonetheless, improved relationships were not only about improving the security of the region and about restoring political stability. The U.S would take advantage of the prevailing situation to improve cooperation with the region in terms of cultural exchanges, trade, and educational opportunities. Further, the U.S promised to remain supporting the efforts of the UN in the region by keeping its troops in Syria to aid in fighting the ISIS in Syria. Their coalition efforts, they noted would not support any parts of Syria still held by Assad with the support of Iran until the Iranian proxy forces completely withdrew from the region. The coalition approach, the U.S noted would only succeed if they continued to support the UN-backed efforts to end the political instability in the region and the conflicting interests to allow for the safe return of millions of Syrian refugees who fled their country as a result of the ISIS and Assad invasion in their homeland. 
Another notable effort of the coalition-building to improve the security in the region that also led to improved ties between the U.S and the Middle East state was the formation of the Middle East Strategic Alliance (MESA). MESA, established to promote a multilateral approach to issues of political, security, energy, and economic conditions of the region and partner states. Consequently, the efforts of MESA were expected to counter the influence of Iran in the region and also to empower the partners in the body to contribute positively to the security operations in the region. Although the coalition team's efforts and strategies could take time to be realized, it is evident that the approach taken by the U.S going forward in its actions in the Middle East will bear noticeable results. Moreover, it would only by working in partnerships with strategic allies and partners that peace and steadiness in the region could be accomplished since single efforts in the past like the war in Iraq did not achieve the desired results.

\subsection{Critical Partners}

The U.S needed strategic and critical partners in the region to be able to influence the return to normalcy and democracy in the region. Such partners should be not only other foreign countries but also Middle East countries that were severely affected by the unrests and instability in the region. According to Eksi (2017), the U.S considered Saudi Arabia and Turkey as some of their most critical allies in the region in its endeavors to promote peace, democracy, and stability because of their strategic locations and their foreign policies (Siddiqui, \& Upadhyay, 2019). Therefore, they considered Saudi Arabia and Turkey to be critical in the agenda of thwarting the actions of Iran in the region as well as an ally in supporting the activities of the UN to bring to an end the war in Yemen (Berti, \& Guzansky, 2014). Further, the U.S believed that their interests would be served better through Saudi Arabia and Turkey if the two countries were also strong and stable politically and economically. In this regard, the U.S continued to consult with the governments of Saudi and Turkey on several issues that affected the region that included the imprisonment of human rights campaigners and extra-judicial executions witnessed in the region. Besides peaceful resolutions to conflicts in the Middle East and world over, coalition building around conflict regions was another strategy that was adopted by the U.S for its future conflict resolution arrangements. Therefore, the identification of strategic partners in areas prone to conflicts would be one key area of focus for the U.S. For example, in the search for a peaceful settlement to the Yemeni unrest, the U.S supported all the efforts of the UN special envoy to the area that was mandated to ensure that the parties to the conflict implemented the agreement reached in Stockholm over the issue.

\subsection{Humanitarian Assistance in Iran and the Middle East}

During conflicts and unrests such as those witnessed in Iran, humanitarian conditions would usually deteriorate owing to several factors. For example, people in conflict areas would be exposed to environments that would not allow them to participate in revenue generation accomplishments. Basic needs such as shelter, healthcare, food, and clothing, among other necessities would not be easily available to the mainstream of the people affected by the unrests. A bigger percentage of the people caught in these situations would be civilians who may not have the capacity to shield themselves in such scenarios or even to raise their voices. Consequently, such people could die of hunger, starvation, malnutrition, diseases, or even as a result of fatalities arising from the fighting. In this regard, the U.S had always been steadfast to ensure that civilians are not exposed to dehumanizing conditions, the conflicts notwithstanding. Going forward, the U.S would have to use their coalition partners to build strong foundations for raising the necessities required by the affected population. Such aid would be useful in helping the people affected or displaced by the violence to return to their homes and to reestablish their lives. Such funding would also include key areas such as security maintenance, medical aid to the people, provision of safe water for drinking, and other support as would be necessary for the prevailing situations. The U.S believed that only a political solution to the problems in Iran would finally end the humanitarian conditions in the area. That formed the basis why the U.S has always maintained its backing for the determinations initiated by the $\mathrm{UN}$ to help find a solution to the problems in Iran. Consequently, going forward and into the future, the U.S would need to back every effort initiated by the UN and give out whatever assistance it would have in its coffers through the UN and any other regional bodies mandated to spearhead the peace processes.

In addition to the traditional form of humanitarian aid to people in areas with conflicts, the U.S also focused on supporting the religious minorities that have been persecuted in their homelands as a result of extremist religious affiliations (Gause III, 2014). For example, in Iraq, the religious minorities had been a constant target for elimination by the extremist ISIS because of their religious affiliation. The U.S in this regard offered to support these groups by supporting their religious freedoms as a key priority. Support to these people included saving their lives in the hands of the attackers, helping them in rehabilitating critical infrastructures like their places of worship, funding justice, and accountability ventures, and offering psychological and legal support to these people. Together with the coalition partners, the U.S would also help in clearing and removing the remaining explosives of 
war in these areas. According to the U.S, the factional religious divisions were one area that Iran exploited in its activities in the region to promote violence, discord, alongside the promise of the U.S to value the self-worth of every human life and to protect their rights no matter where they would be. Subsequently, adherence to the rule of law, in addition to democratic and accountable governments, was the attention of the U.S and its allies in the region. In the spirit of democracy, the U.S and its coalition expect the governments to respect and protect the religious freedoms of every individual irrespective of their sectarian interests.

\subsection{The Influence of Other International Players in the Middle East}

The Middle East is a region naturally endowed with huge deposits of oil that forms the backbone of the region's economy. As a result, several countries, including the U.S look up to the regions oil wells to power their industrial growth and economic prosperity. The presence of oil in the region also attracted several international players who in the end, played a chief role in shaping the conflicts in the region and Iran in particular. The participation of these countries has also informed the future engagements of the U.S in the region. After the sanctions imposed on Iranian oil exports by the U.S, most of the region's oil exports have shifted to China and East Asia in general. To compensate for the oil exports, China, in return, offering loans and financial investments in the region that posed a major threat to the American influence and engagement in the region (Dorsey, 2018). China, also keen to enforce itself as a world power has also in the recent past been keen to counter any American influence in the world. For example, they set up an overseas military base in Djibouti to help in the protection of their international interests in the Middle East (Davies, Draper, \& Edinger, 2014). The dynamics that have played in the area as China and East Asia seek to promote their influence in the world have seen several delegations from the Middle East travel to Asia putting the realization of any peace deal in jeopardy. While China could be right in its efforts to compete with the U.S, its efforts at blackmailing the peace efforts have thus put the Middle East region instability in a critical situation. For example, China and East Asia continue to import oil from the Middle Eastern countries including Iran, financial revenue that the U.S would want to be cut to starve Iran of the financial muscle it uses to support terrorist activities. The involvement of the Asia countries in this conflict thus put the U.S under check, which forced Washington to reconsider its future engagements in the Middle East.

\section{Recommendations and Conclusion}

As argued all through this paper, it has been evident that the U.S can no longer afford to go it alone in its efforts to find peace and restore stability in Iran. Therefore, it has been argued that the U.S should consider its options while attempting to get involved in any peace process in Iran (Bilgin, 2019). In addition to the recommendations of senior officials in the Washington Administration, technology could also be another major input in the struggles to contain the instability in Iran. Part of the approaches that the U.S identified could be essential to finding a lasting solution to the problems was coalition building. In coalition building, all the parties would need to understand the challenges in the region and approach them as a united front. Currently, while there would be countries that understand the issues of Iran, there is another wing that seems desperate for attention and would do everything to scuttle the advances made by other bodies and countries. Consequently, in the spirit of coalition building, the U.S together with its coalition partners need to engage with China and the other Eastern Asia nations to find a united approach on how to handle Iran.

Notably, the Chinese, the Israeli, and the Americans have spearheaded the current technological advancements in the world. When doing security surveillance in the contemporary world, technology would play a major role in combating crime and apprehending criminals at their doorsteps (Ronczkowski, 2017). If the U.S would wish to further their participation in Iran in the future and help in the return of peace and democracy in the region, their coalition-building ventures should go beyond the region and embrace other international actors in the economic activities in the region like China (Paul et al., 2018). In this regard, they should engage with them and develop technological measures that could help them in countering the influences of terrorists and their financiers in the region (Chaturvedi, Unal, Aggarwal, Bahl, \& Malik, 2014). An all-inclusive tactic that does not exclude any player in the region would guarantee a return to democracy, peace, and stability in the region.

The encounters experienced by the U.S in Iran could be complex, given the nature of the battles and the actors involved in the conflicts. From another view, the U.S could have misconstrued the degree of the conflicts in Iran, and admittedly, one of their greatest blunders was the war in Iraq. However, as it stands, replacing the role the U.S has played in trying to end the conflicts in Iran may not be easy. As a result, the U.S needs to do is to reconsider its policies on how its participation in the region would be going forward. Their support for a peaceful determination to the unrests aside, the U.S needs to be engaged in expanding its coalition-building initiatives to include countries like China and other Eastern Asia nations like the JCPOA deal that was signed between them, Europeans, Russia, and China on imposing sanctions on Iran. Also, in their future engagements in Iran, the U.S would need to pay 
attention to the roots and the consequences of the sectarian religious differences in the region to understand and mitigate their role in the escalation of the conflicts in the region. Overall, the U.S will have to be engaged further in the negotiations and conflict resolutions in Iran. To have their presence felt, they will have to embrace and support any UN-led or coalition-led approaches to the issues at hand and not merely by arm-twisting the protagonists in the conflict. They would also need to embrace the U.S of technology in surveillance and apprehension of criminal gangs and their financiers. Further, they would need to bring together all the nations that have influenced the world technologically to put together a team that could help them achieve this objective.

\section{References}

Berti, B., \& Guzansky, Y. (2014). Saudi Arabia's foreign policy on Iran and the proxy war in Syria: Toward a new chapter? Israel Journal of Foreign Affairs, 8(3), 25-34. https://doi.org/10.1080/23739770.2014.11446600

Bilgin, P. (2019). Regional security in the Middle East: A critical perspective. Routledge, 112-128. https://doi.org/10.4324/9781315204123

Byman, D. (2014). Sectarianism afflicts the new Middle East. Survival, 56(1), 79-100. https://doi.org/10.1080/00396338.2014.882157

Chaturvedi, M., Unal, A., Aggarwal, P., Bahl, S., \& Malik, S. (2014, June). International cooperation in cyber space to combat cyber crime and terrorism. In 2014 IEEE Conference on Norbert Wiener in the 21st Century (21CW) (pp. 1-4). IEEE. Tajbakhsh, K. 019. https://doi.org/10.1109/NORBERT.2014.6893915

Chomsky, N., Achcar, G., \& Shalom, S. R. (2015). Perilous power: The Middle East and U.S foreign policy dialogues on terror, democracy, war, and justice. Routledge. https://doi.org/10.4324/9781315632865

Claes, D. H. (2018). Oil and the U.S hegemony. In The Politics of Oil. Edward Elgar Publishing. Retrieved July 22, 2019, from https://www.e-elgar.com/shop/the-politics-of-oil

Constantin-Bercean, I. (2018). A Nuclear Test for Diplomacy: Iran and the (New) Eu-Us Sanctions Debate. Modelling the New Europe. An On-line Journal, (28), 182-205. https://doi.org/10.24193/OJMNE.2018.28.10

Cordesman, A. H. (2018). Perilous Prospects: The Peace Process and the Arab-Israeli Military Balance. Routledge. https://doi.org/10.4324/9780429498404

Davies, M., Draper, P., \& Edinger, H. (2014). Changing China, Changing Africa: Future Contours of an Emerging Relationship. Asian Economic Policy Review, 9(2), 180-197. https://doi.org/10.1111/aepr.12059

Dorsey, J. M. (2018). How Much Solidarity with Iran can the China-led SCO afford?. IndraStra Global, 4(5), 5.

Duncombe, C. (2019). U.S representations of Iran and its nuclear program. In Representation, recognition and respect in world politics. Manchester University Press. https://doi.org/10.7765/9781526124920.00015

Ekşi, M. (2017). Regional Hegemony Quests in the Middle East from the Balance of Power System to the Balance of Proxy Wars: Turkey as Balancing Power for the Iran-Saudi Rivalry. Gazi Akademik Bakış, 11(21), 133-156. https://doi.org/10.19060/gav.379597

Gause III, F. G. (2014). Beyond sectarianism: The new Middle East cold war. Brookings Doha Center Analysis Paper, 11, 1-27.

Hinnebusch, R. (2018). Foreign policy making in the Middle East. In The international politics of the Middle East. Manchester University Press. https://doi.org/10.7765/9781526137760.00010

Kovjanić, G. (2014). Islamic tourism as a factor of the Middle East regional development. Turizam, 18(1), 33-43. https://doi.org/10.5937/Turizam1401033K

Krieg, A. (2016). Externalizing the burden of war: the Obama Doctrine and U.S foreign policy in the Middle East. International Affairs, 92(1), 97-113. https://doi.org/10.1111/1468-2346.12506

Lowenthal, M. (2018). Nuclear Disarmament and Non-proliferation Today and in the Near Future. In International Cooperation for Enhancing Nuclear Safety, Security, Safeguards and Non-proliferation-60 Years of IAEA and EURATOM (pp. 195-202). Springer, Berlin, Heidelberg. https://doi.org/10.1007/978-3-662-57366-2_29

Marantz, P., Steinberg, B., Sigler, J., \& Sandler, S. (2019). Superpower involvement in the Middle East: dynamics of foreign policy. Routledge. https://doi.org/10.4324/9780429307942

Paffenholz, T., \& Zartman, I. W. (2019). Inclusive Peace Negotiations-From a Neglected Topic to New Hype. International Negotiation, 24(1), 1-6. https://doi.org/10.1163/15718069-24011186

Paul, C., Clarke, C. P., Schwille, M., Hlávka, J. P., Brown, M. A., Davenport, S. S., ... \& Harding, J. (2018). 
Lessons from Others for Future U.S Army Operations in and Through the Information Environment. RAND Corporation. https://doi.org/10.7249/RR1925.2

Ronczkowski, M. R. (2017). Terrorism and organized hate crime: Intelligence gathering, analysis, and investigations. CRC press. https://doi.org/10.4324/9781315203133

Siddiqui, F. R., \& Upadhyay, D. K. (2019). Warsaw Middle East Conference and U.S Ties with Europe and Arab World.

Tajbakhsh, K. (2019). Getting Real About Iran. Foreign Affairs. Retrieved July 20, 2019, from https://www.foreignaffairs.com/articles/iran/2019-03-19/getting-real-about-iran

Tielemans, A. (2019). Iran and UAE in Yemen. Retrieved July 15, 2019, from http://iar-gwu.org/2019/05/28/iran-and-uae-in-yemen-regional-and-global-ambitions/

\section{Copyrights}

Copyright for this article is retained by the author(s), with first publication rights granted to the journal.

This is an open-access article distributed under the terms and conditions of the Creative Commons Attribution license (http://creativecommons.org/licenses/by/4.0/). 